\title{
Flowering Phenology, Stalk Anatomy and Vase Life of Four Cultivars of Gerbera hybrida (Flowering Phenology, Stalk Anatomy of Gerbera)
}

\author{
SORINA A. PETRA ${ }^{1}$, MIHAELA I. GEORGESC ${ }^{1 *}$, CRISTINA R. MANESCU ${ }^{1}$, FLORIN TOMA $^{1}$, \\ IOANA M. PADURE ${ }^{3}$, ELENA SĂVULESCU ${ }^{2}$, ELISABETA DOBRESCU ${ }^{1}$
}

\begin{abstract}
${ }^{1}$ University of Agronomic Sciences and Veterinary Medicine of Bucharest, Faculty of Horticulture, Department of Landscape architecture, Biodiversity and Ornamental plants, 59 Marasti Boulevard, District 1, 011464, Bucharest, Romania

${ }^{2}$ University of Agronomic Sciences and Veterinary Medicine of Bucharest, Faculty of Horticulture, Department of Bioengineering of Horti-Viticultural Systems, 59 Marasti Boulevard, District 1, 011464, Bucharest, Romania

${ }^{3}$ Universalmuseum Joanneum, Natural History Museum, Weinzöttlstraße 168045 Graz, Österreich, Austria;
\end{abstract}

\begin{abstract}
Flowering phenology is an important feature for producers to establish planting time and time of harvest. Because each cultivar reacts different in similar growth conditions, due to their complex genetic inheritance, studies may initiate to evaluate their performance. Cultivars 'Aladin', 'Anita', 'Creme Eye' and 'Navelino' were investigated during autumn-winter regarding flowering phenology, stalk anatomy and vase life of cut flowers. Results showed some differences among cultivars. Cultivars needed 55-58 days from planting to flowers harvesting, but the intermediate phases were dissimilar. Transverse sections of stalk in the apical and median zone showed that cultivars developed structures to sustain the inflorescence, thus the neck bending and stalk bending had an insignificant occurrence. Except 'Creme Eye', all the cut flowers performed best in tap water, with a vase life of 15.2-19.1 days. Cultivars proved suitable for greenhouse cultures in Romania.
\end{abstract}

Keywords Gerbera hybrida, bud initiation, inflorescence, sclerenchyma, vase solutions.

To cite this article: PETRA SA, GEORGESCU MI, MANESCU CR, TOMA F, PADURE IM, SĂVULESCU E, DOBRESCU E. Flowering Phenology, Stalk Anatomy and Vase Life of Four Cultivars of Gerbera hybrida (Flowering Phenology, Stalk Anatomy of Gerbera). Rom Biotechnol Lett. 2020; 25(3): 1635-1640. DOI: 10.25083/rbl/25.3/1635.1640

*Corresponding author: MIHAELA IOANA GEORGESCU, University of Agronomic Sciences and Veterinary Medicine of Bucharest, Faculty of Horticulture, Department of Landscape architecture, Biodiversity and Ornamental plants, 59 Marasti Boulevard, District 1, 011464, Bucharest, Romania; Tel. +40728023011; postal address: 59 Marasti Boulevard, District 1, Bucharest, Romania; zip code: 011464

E-mail: mihaelaigeorgescu@yahoo.com; 


\section{Introduction}

Cultivars of Gerbera hybrida are extremely appreciated worldwide for the flowers coming in a different range of colour, shape and size. Due to their complex genetic inheritance - Gerbera jamesonii x Gerbera viridifolia, and probable some other species (TOURJEE et al, 1994; HANSEN, 1999), cultivars proved different reaction to growth conditions (MENG et al, 2004; HATAMZADEH et al, 2012; LI et al, 2019; CANTOR and BUTA, 2011) and postharvest longevity (WERNETT et al, 1996).

In order to acquire the maximum yield of quality flowers, producers have to consider not only Gerbera cultivars' requirements, but also to take knowledge about flowering phenology at each cultivar they grow. In Europe, flowering of Gerbera is problematic during winter months, mainly because of the impossibility to establish a good relationship among day length, temperature and light level (DE VISSER et al, 2010; DE GELDER et al, 2014; DUECK et al, 2017). Although Gerbera is a short day plant, it produces fewer flowers as the nights become shorter and supplying light during winter have positive effect on yield (AUTIO, 2000; PETTERSEN and GISLEROD, 2003; CRISTIANO et al, 2008).

Although, the postharvest life span of the cut flowers varies with the cultivars (MAHMOOD et al, 2013; BISWAL et al, 2017; ZAHARIA et al, 2018), growing season had also an influence on the vase-life longevity. In some cultivars, the longest vase-life (18.37 days) was found in flowers harvested in winter (ACHARYA et al, 2010).

The purpose of this work was to investigate the flowering phenology, stalk anatomy and vase life of cut flowers of four cultivars of Gerbera hybrida, in greenhouse conditions, during autumn-winter, in order to establish their performance and provide helpful information to growers and consumers.

\section{Material and Methods}

Investigations were carried out during September December 2019 on plants of four cultivars of Gerbera hybrida ('Aladin', 'Anita', 'Creme Eye' and 'Navelino'), at the University of Agronomical Sciences in Bucharest (latitude $44^{\circ} 24^{\prime} 49^{\prime \prime} \mathrm{N}$ and longitude $26^{\circ} 05^{\prime} 48^{\prime \prime E}$ ), Romania. In September, plugs were planted in individual plastic pots (diameter $=18 \mathrm{~cm}$, height $=16 \mathrm{~cm})$ containing a mixture of garden soil, sawdust compost, peat and perlite in a volume ratio of 1:1:1:0.25. Pots were placed in a greenhouse with hanging growing gutter system, under natural illumination, at $20-24^{\circ} \mathrm{C}$. Nutritive solutions containing $\mathrm{N}: \mathrm{P}: \mathrm{K}$ in a volume ratio of $3: 1: 5$, were distributed with the water through drip irrigation system. For flowering phenology, 20 plants from each cultivar were observed once at three days, from the flower budsinitiation to wilting flower.

For anatomical investigations, hand cross-sections of flower stems were carried outin two zones, beneath inflorescence (apical zone) and at $15 \mathrm{~cm}$ below it (median zone). The sections were clarified with chloral hydrate in saturated solution, for 24 hours and washed with tap water. Observations and measurements were performed with the Leica DM 1000LED microscope, with the eye piece lens of $10 \mathrm{x}$ and objective lenses $25 \mathrm{x}$, provided with LAS-CORE software. Photos were taken with the DFC 295 camcorder.

Vase life was tested in December 2019, whenten flowers from each cultivarwere harvested in the morning at the commercial maturity (when the two outer whorls of flowers in the floral head showed mature stamens). The experience was designed to reproduce the conditions that consumers can provide at home. Therefore, stalks end were cut in water at $35 \mathrm{~cm}$ length and then placed individually in $100 \mathrm{ml}$ glass cylinders, filled with : $\mathrm{S}_{0}-$ tap water (control); $\mathrm{S}_{1}-$ lemon juice $2 \%+$ sucrose $1 \%+0.2 \%$ bleach; $\mathrm{S}_{2}-$ colourless soft drink $50 \%+1 / 2$ tablet aspirin; $\mathrm{S}_{3}$ - a commercial universal preservative for cut flowers; $\mathrm{S}_{4}$ - a commercial cut flower food. The flowers were kept in a room with indirect light, at an average air temperature of $22-24^{\circ} \mathrm{C}$.

Data were analyzed statistically using one-way ANOVA test and significance of the difference among means was estimated with LSD (Least Significant Difference) Post Hoc Test at 5\% level of significance.

\section{Results}

Flowering phenology varied with the cultivar (Table 1). Flowers were ready to be harvested after 55.05-58.05 days after planting.

Table 1. Phenological response of Gerbera hybrida cultivars

\begin{tabular}{|c|c|c|c|c|c|c|}
\hline Cultivars & $\begin{array}{c}\text { Days from } \\
\text { planting to } \\
\text { harvest }\end{array}$ & $\begin{array}{c}\text { Days from } \\
\text { planting to bud } \\
\text { initiation }\end{array}$ & $\begin{array}{c}\text { Days from bud } \\
\text { initiation to } \\
\text { harvest }\end{array}$ & $\begin{array}{c}\text { Days from } \\
\text { harvest to } \\
\text { wilting flower }\end{array}$ & $\begin{array}{c}\text { Inflorescence } \\
\text { diameter }(\mathbf{c m})\end{array}$ & $\begin{array}{c}\text { Stalk } \\
\text { length } \\
(\mathbf{c m})\end{array}$ \\
\hline Aladin & $58.05 \mathrm{a}$ & $27.10 \mathrm{a}$ & $31.90 \mathrm{a}$ & $15.20 \mathrm{a}$ & $7.46 \mathrm{c}$ & $44.72 \mathrm{~b}$ \\
\hline Anita & $55.10 \mathrm{~b}$ & $23.80 \mathrm{c}$ & $32.00 \mathrm{a}$ & $10.35 \mathrm{~d}$ & $8.51 \mathrm{a}$ & $47.54 \mathrm{a}$ \\
\hline Creme Eye & $55.20 \mathrm{~b}$ & $27.15 \mathrm{a}$ & $29.25 \mathrm{c}$ & $11.45 \mathrm{c}$ & $7.71 \mathrm{~b}$ & $41.50 \mathrm{c}$ \\
\hline Navelino & $55.05 \mathrm{~b}$ & $24.90 \mathrm{~b}$ & $31.05 \mathrm{~b}$ & $13.05 \mathrm{~b}$ & $7.02 \mathrm{~d}$ & $39.63 \mathrm{~d}$ \\
\hline $\begin{array}{c}\text { LSD }(P \leq \\
0.05)\end{array}$ & 0.26 & 0.30 & 0.23 & 0.36 & 0.11 & 0.85 \\
\hline
\end{tabular}

(LSD - Least Significant Difference)

All data within columns with the same letter are not statistically different at $P \leq 0.05$. 
Although three of the cultivars - 'Anita', 'Creme Eye' and 'Navelino', needed 55 days to grow and develop until harvest, the intermediate phases were quite different. First cultivar that initiated flower buds was 'Anita' (23.80 days after planting). At the rest of cultivars bud initiation was observed soon after (in 1-3 days). The time required for flowers to reach the commercial stage for harvest varied between 29.25 days ('Creme Eye') and 32.00 days ('Anita'). The largest inflorescence $(8.51 \mathrm{~cm})$ was measured at 'Anita' cultivar and the smallest $(7.02 \mathrm{~cm})$ at 'Navelino'. Inflorescences development differed with the cultivars (Fig. 1).

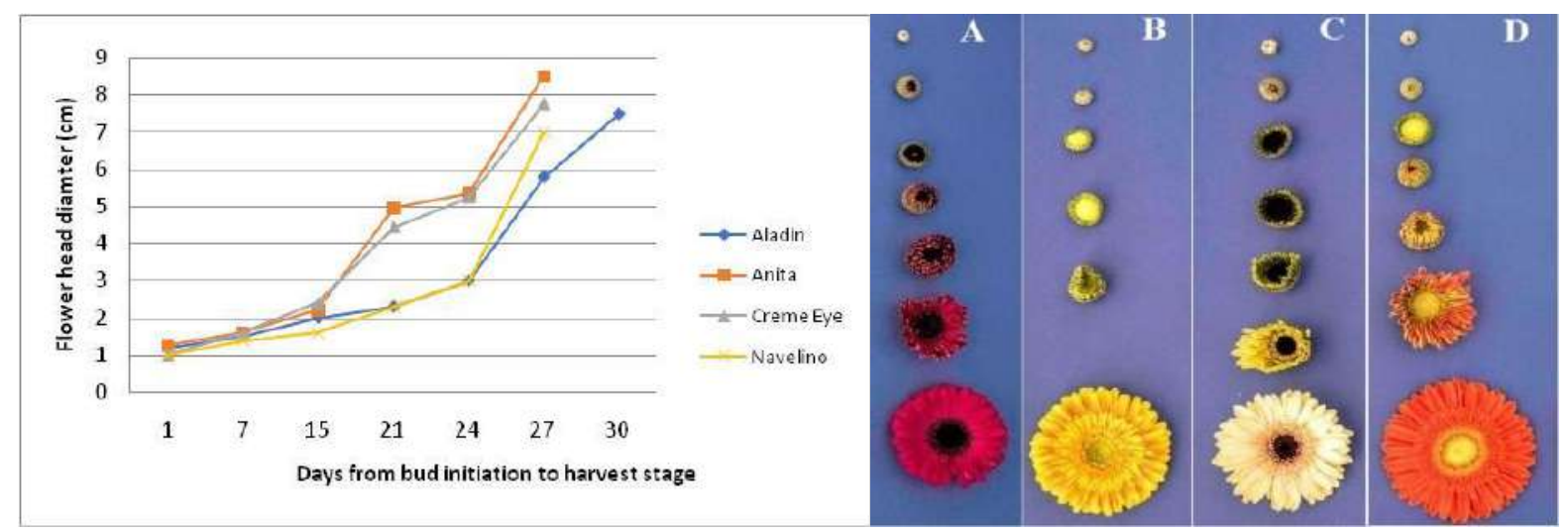

Figure 1. Dynamic of inflorescences development from bud initiation to harvest. (A - Aladin; B - Anita; C - Creme Eye; D - Navelino)

After 15 days from bud initiation, cultivars 'Anita' and 'Creme Eye' had an intense development, flowers doubling their size in five days. For the other two cultivars, flowers increased more in size after 21 days. Stalk length varied also with the cultivar, with a minimum value of $39.63 \mathrm{~cm}$ at 'Navelino' and a maximum value of $47.54 \mathrm{~cm}$ at 'Anita', at the time of harvest. Inflorescence life span on plant, after commercial stage of harvest, varied from 15.02 days ('Aladin') to 10.35 days ('Anita').

Stalk transverse sections showed slightly differences among cultivars. The epidermal cells areisodiametic, single-layered and covered with cuticle (Fig. 2). Excepting the 'Creme Eye', all cultivars may havetector trichomes on epidermis. The parenchyma cells were almost isodiametric at all cultivars. At 'Creme Eye' cultivar first layers of parenchyma were slightly collenchymatic. The parenchyma layer appeared much larger in apical than in median zone at all cultivars (Table 2). Central cylinder was delimited by a sclerified pericycle and the vascular bundles of various sizedwere placed alternately. In apical zone, pericycle appeared as an interrupted sclerenchymatic ring, evident only next to vascular bundles. In median zone, pericycle formed a continuous ring, much more developed next to the vascular bundles.

All cultivars presented a decrease of sclerenchyma next to the vascular bundles from the median to the apical zone, as well as the thickness of the cell walls.
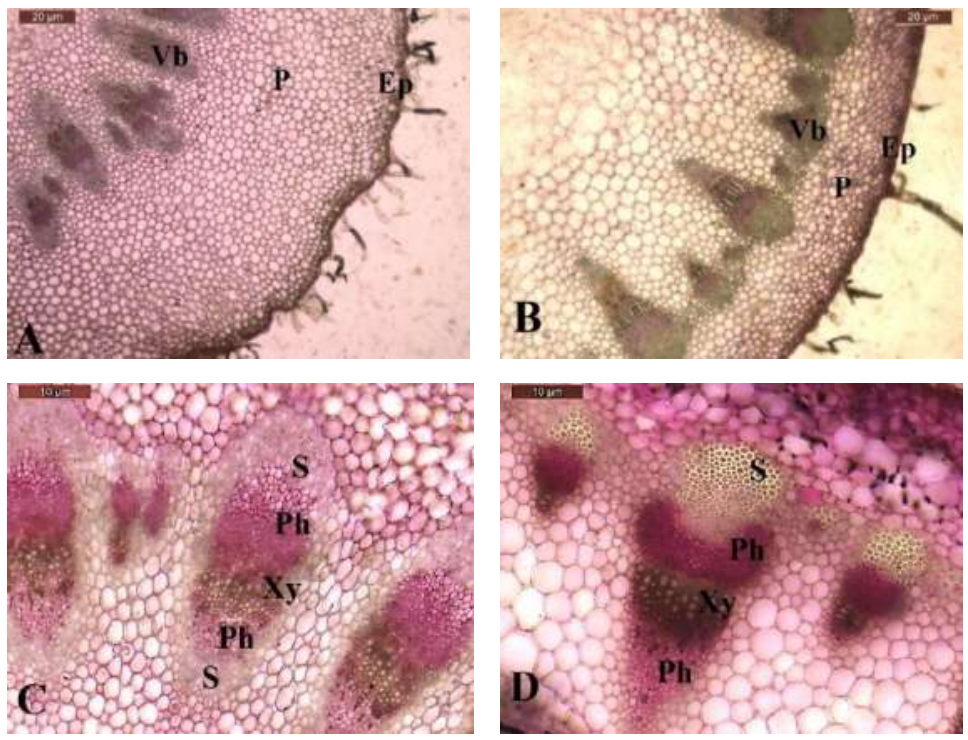

Figure 2. Microscopic images of stalk section: A) apical zone; B) median zone; C) details of central cylinder in apical zone; D) details of central cylinder in median zone. (Abbreviations: Ep - Epidermis, $\mathrm{P}$ - Parenchyma, $\mathrm{Ph}$ - Phloem, $\mathrm{S}$ - Sclerenchyma, Vb - Vascular bundle, Xy - Xylem). 
Table 2. Stalk anatomy characteristics of four cultivars of Gerbera hybrida

\begin{tabular}{|c|c|c|c|c|c|c|c|c|}
\hline $\begin{array}{c}\text { Characteristics } \\
(\boldsymbol{\mu} \mathbf{m})\end{array}$ & \multicolumn{2}{|c|}{ Aladin } & \multicolumn{2}{c|}{ Anita } & \multicolumn{2}{c|}{ Creme Eye } & \multicolumn{2}{c|}{ Navelino } \\
\cline { 2 - 9 } & Apical zone & Median zone & Apical zone & Median zone & Apical zone & Median zone & Apical zone & Median zone \\
\hline Parenchyma & 494.2 & 224.1 & 450.7 & 224.7 & 482.9 & 220.3 & 525.4 & 260.1 \\
\hline $\begin{array}{c}\text { Vascular bundle } \\
\text { length }\end{array}$ & 361.4 & 512.9 & 399.3 & 470.6 & 359.5 & 458.3 & 348.6 & 446.7 \\
\hline Sclerenchyma & 77.3 & 148.8 & 85.8 & 152.1 & 70.9 & 134.9 & 83.4 & 121.8 \\
\hline Upper phloem & 108.1 & 72.9 & 103.6 & 53.5 & 100.2 & 56.7 & 86.5 & 60.7 \\
\hline Xylem & 90.6 & 95.0 & 95.8 & 88.4 & 70.3 & 91.1 & 85.3 & 86.7 \\
\hline Lower phloem & 82.9 & 127.0 & 56.9 & 48.2 & 63.1 & 106.9 & 78.3 & 79.8 \\
\hline
\end{tabular}

In the apical area, cultivar 'Anita' formed an extended sclerenchyma, but the cell walls were very slightly thickened. Vascular bundles were bicollateral type, with the xylem delimited by an extensive upper phloem and a smaller lower phloem. The length of vascular bundles decreases from the median to the apical zone at all cultivars.Flowerstalks kept in water had increased vase life relative to other solutions, for all cultivars except 'Creme Eye' (Table 3).

Table 3. Reaction of cultivars to different vase solutions

\begin{tabular}{|c|c|c|c|c|c|c|}
\hline \multirow{2}{*}{ Parameters } & \multirow{2}{*}{ Solution } & \multicolumn{4}{|c|}{ Cultivars } & \multirow{2}{*}{ LSD* } \\
\hline & & Aladin & Anita & Creme Eye & Navelino & \\
\hline \multirow{5}{*}{ Vase life (days) } & $\mathrm{S}_{0}$ & $19.1 \mathrm{a}$ & $15.2 \mathrm{c}$ & $14.2 \mathrm{~d}$ & $16.0 \mathrm{~b}$ & 0.31 \\
\hline & $\mathrm{S}_{1}$ & $16.3 \mathrm{~b}$ & $15.1 \mathrm{c}$ & $16.9 \mathrm{a}$ & $8.2 \mathrm{~d}$ & 0.35 \\
\hline & $\mathrm{S}_{2}$ & $12.1 \mathrm{~b}$ & $9.3 \mathrm{~d}$ & $14.1 \mathrm{a}$ & $11.4 \mathrm{c}$ & 0.37 \\
\hline & $\mathrm{S}_{3}$ & $13.7 \mathrm{c}$ & $14.4 \mathrm{~b}$ & $17.2 \mathrm{a}$ & $11.9 \mathrm{~d}$ & 0.50 \\
\hline & $\mathrm{S}_{4}$ & $17.5 \mathrm{a}$ & $9.1 \mathrm{~d}$ & $15.4 \mathrm{~b}$ & $11.4 \mathrm{c}$ & 0.57 \\
\hline \multirow{5}{*}{ Solution uptake (ml) } & $\mathrm{S}_{0}$ & $30.4 \mathrm{~b}$ & $30.3 \mathrm{~b}$ & $32.0 \mathrm{a}$ & $31.4 \mathrm{a}$ & 0.84 \\
\hline & $\mathrm{S}_{1}$ & $39.0 \mathrm{~b}$ & $34.5 \mathrm{c}$ & $33.6 \mathrm{c}$ & $40.9 \mathrm{a}$ & 1.70 \\
\hline & $\mathrm{S}_{2}$ & $34.7 \mathrm{~b}$ & $37.0 \mathrm{a}$ & $33.2 \mathrm{c}$ & $31.4 \mathrm{~d}$ & 0.71 \\
\hline & $\mathrm{S}_{3}$ & $33.3 \mathrm{~b}$ & $30.1 \mathrm{c}$ & $37.6 \mathrm{a}$ & $33.8 \mathrm{~b}$ & 0.96 \\
\hline & $\mathrm{S}_{4}$ & $29.8 \mathrm{c}$ & $37.3 \mathrm{~b}$ & $39.4 \mathrm{a}$ & $36.5 \mathrm{~b}$ & 1.19 \\
\hline \multirow{5}{*}{ Stalk elongation (mm) } & $\mathrm{S}_{0}$ & $70.3 \mathrm{a}$ & $0.1 \mathrm{~d}$ & $20.4 \mathrm{c}$ & $35.2 \mathrm{~b}$ & 0.57 \\
\hline & $\mathrm{S}_{1}$ & $35.5 \mathrm{a}$ & $5.1 \mathrm{~d}$ & $30.9 \mathrm{~b}$ & $20.8 \mathrm{c}$ & 0.93 \\
\hline & $\mathrm{S}_{2}$ & $80.2 \mathrm{a}$ & $0.2 \mathrm{~d}$ & $30.6 \mathrm{c}$ & $35.0 \mathrm{~b}$ & 0.65 \\
\hline & $\mathrm{S}_{3}$ & $75.7 \mathrm{a}$ & $50.4 \mathrm{~b}$ & $35.3 \mathrm{~d}$ & $40.4 \mathrm{c}$ & 0.69 \\
\hline & $\mathrm{S}_{4}$ & $70.5 \mathrm{a}$ & $40.7 \mathrm{~b}$ & $30.4 \mathrm{c}$ & $30.8 \mathrm{c}$ & 1.09 \\
\hline
\end{tabular}

*(LSD - Least Significant Difference)

All data within rows with the same letter are not statistically different at $P \leq 0.05$.

However, all the vase solutions preserved the flowers at least 8 days. The longest vase-life was remarked at 'Aladin' cultivar (19.1 days in $\mathrm{S}_{0}$ ). Neck bending problem was observed only in case of cultivar 'Anita', held 9.3 days in solutions $S_{2}$ and 15.1 days in $S_{1}$ (Fig. 3). Stalk bending, another frequent problem of Gerbera flowers shortened vase life at all cultivars kept in solution $S_{2}$. Stalk bending was observed more in case of cultivar 'Navelino'.
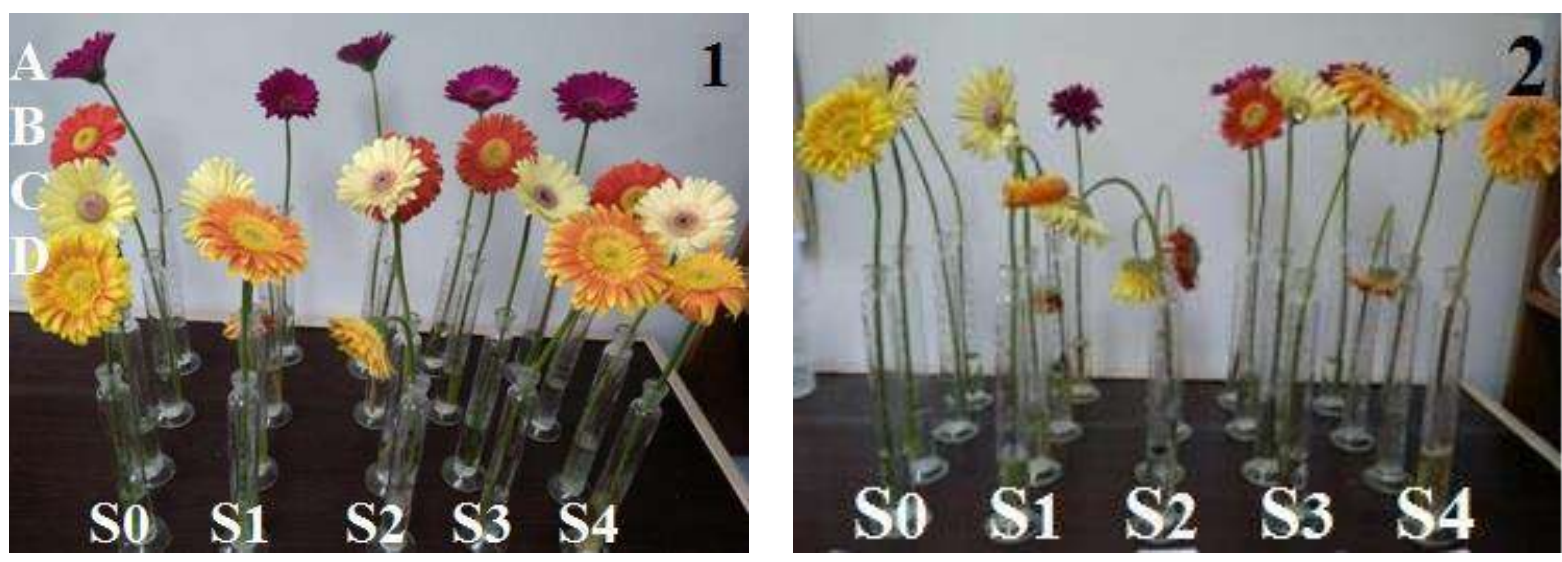

Fig. 3. Aspects from the vase life experiment: (1) after 10 days; (2) after 16 days.

(A - 'Aladin'; B - 'Navelino'; C - 'Creme Eye'; D - 'Anita'. Solutions: S 0 - tap water;

$\mathrm{S}_{1}-$ lemon juice $2 \%+$ sucrose $1 \%+0.2 \%$ bleach; $\mathrm{S}_{2}-$ colourless soft drink $50 \%+1 / 2$ tablet aspirin;

$\mathrm{S}_{3}$ - a commercial universal preservative for cut flowers; $\mathrm{S}_{4}-$ a commercial cut flower food). 
Solution uptake was different with cultivar. The minimum uptake was of $29.8 \mathrm{ml}$ at 'Aladin' on solution $\mathrm{S}_{4}$ and the maximum of $40.9 \mathrm{ml}$ at 'Navelino' on solution $\mathrm{S}_{1}$. Two of the cultivars, 'Aladin' and 'Navelino' absorbed more solution $S_{1}$ and the other two, 'Anita' and 'Creme Eye', solution $\mathrm{S}_{4}$.

Stalk elongation was presentedwith different intensitiesat all cultivars. The greatest tendency of elongationshowed 'Aladin', with values between 35.5-80.2 $\mathrm{mm}$ in different solution, including tap water. In some solutions, 'Anita' cultivar remained at the same stalk length as at the beginning of the experiment $\left(\mathrm{S}_{0}\right.$ and $\left.\mathrm{S}_{2}\right)$ and in other solutions the stalks grew up till $50.4 \mathrm{~mm}\left(\mathrm{~S}_{3}\right)$.

\section{Discussion}

Variations between cultivars regarding flowering phenology were confirmed by other authors (SARKAR and GHIMIRAY, 2004; CHOBE et al, 2010; LONGCHAR and KEDITSU, 2013; PATIL and KULKARNI, 2015). However, the time from planting to harvest was similar for three of the four cultivars in this study ('Anita', 'Creme Eye' and 'Navelino') even if the buds initiation and their development were at a different rate. Autumn planting proved to be favourable for evolution of Gerbera plants, which initiated flowers in less than a month and opened first flowers after 55-58 days from planting. The time needed by Gerbera plants to induce and open flowers depends greatly by cultivar, temperature and light (DENG and HARBAUGH, 2010; PETTERSEN and GISLEROD, 2003; CRISTIANO et al, 2008). Except for 'Navelino' cultivar, inflorescences had have diameters at the upper limit of the producers' indications. Instead the stalk length, which in the case of Gerbera cut-flowers is desirable to be at least $50 \mathrm{~cm}$, it did not exceed this value at any cultivar. Variations in inflorescence diameters and stalk length were reported also by other authors (JEEVAJOTHI et al, 2003; SHAMMY et al, 2012; HOSSAIN et al, 2015), who suggested that they are genetically and environmentally controlled.

Observations at anatomical level revealed the existence of structures to sustain the inflorescence at all cultivars. Although mechanical tissues were absent in apical zone, the thickness of cortical parenchyma can support the inflorescence only by hydration of its cells. Therefore, except 'Creme Eye', all the cut flowers performed best in tap water. Also, neck bending had an insignificant occurrence. For all cultivars, in the median zone parenchyma layers were collenchymaticand consequently the incidence of stalk bending at cut flowers was reduced. Some authors presumed that the stalk strength of cut flowers is closely related with the lignifications of xylem and intervascular sclerenchyma cells (MAROUSKY, 1986; DONALDSON, 2001; PERIK et al, 2012; HAMEDAN et al, 2019).

Independent of vase solutions and cultivar, flowers lived more with 3-6 days in tap water or other solutions than those that remained on the plant, at the same stage (commercial maturity). Despite of fact that water preserved longer time the cut flowers, solutions that were uptaked more were $S_{1}$ at 'Aladin' and 'Navelino' and $S_{4}$ at 'Anita' and 'Creme Eye'. The presence of sucrose and other food components of these solutions could explain the result, similar with other studies (NAIR et al, 2003; MEMAN and DABHI, 2006; KHAN et al, 2015).

\section{Conclusions}

Studies on flowering phenology revealed differences among cultivars. The quality of the inflorescences obtained during autumn-winter period, expressed by their diameter and stalk length was satisfactory for all four cultivars. Also, the postharvest quality of the cut flowers was reasonable. The anatomy of the stalks revealed that all cultivars presents structures, which can prevent neck bending and stalk bending, even if the vase solution is simply water. However, more researches are needed to test the different planting time, because is generally known the influence of light and temperature on the performance of Gerbera cultivars. Due to the stalk elongation problem, cultivar 'Aladin' is not recommended for combination with other flower in mixed bouquets or flower arrangements.

\section{Acknowledgements}

This research received no specific grant from any funding agency in the public, commercial, or not-forprofit sectors.

\section{References}

1. ACHARYA AK, BARAL DR, GAUTAM D, PUN UK. Influence of seasons and varieties on vase life of gerbera (Gerbera jamesonii Hook.) cut flower. Nepal J Sci Technol. 2010; 11: 41-46.

2. AUTIO J. Supplementary lighting regimes strongly affect the quantity of gerbera flower yield. Acta Hortic. 2000; 515: 91-98.

3. BISWAL M, PALAI SK, CHHURIA S, SAHU P. Evaluation of exotic cultivars of gerbera (Gerbera jamesonii L.) under naturally ventilated polyhouse in Western Odisha. J Krishi Vigyan 2017; 5(2): 70-76.

4. CANTOR M, BUTA E. Researches concerning the behaviour of Gerbera hybrida cultivars in pots. Sci Papers - Series B, Hortic. 2011; 55: 210-215.

5. CHOBE RR, PACHANKAR PB, WARADE SD. Performance of different cultivars of gerbera under polyhouse condition. Asian J Hortic. 2010; 5(2): 333-335.

6. CRISTIANO G, COCOZZA TALIA MA, LA VIOLA AMF et al. Influence of supplementary lighting on autumn-winter yield of four gerbera (Gerbera jamesonii) cultivars. Acta Hortic. 2008; 801: 1049-1054.

7. DENG Z, HARBAUGH BK. UFGE 4141, UFGE 7014, UFGE 7015, UFGE 7023, UFGE 7032, and UFGE 7034: Six New Gerbera Cultivars for Marketing Flowering Plants in Large Containers. HortScience. 2010; 45(6): 971-974. 
8. DONALDSON LA. Lignification and lignin topochemistry - an ultrastructural view. Phytochemistry 2001; 57: 859-873.

9. DE GELDER A, WARMENHOVEN MG, DIELEMAN JA. Sustainable gerbera production realised with the next generation greenhouse cultivation. Acta Hortic. 2014; 1037: 701-708.

10. DUECK TA, KEMPKES FLK, VAN DER HELM F, DE GROOT M. Influence of light and temperature on flower development in gerbera. Acta Hortic. 2017; 1170: 943-950.

11. HAMEDAN HJ, SOHANI MM, AALAMI A, NAZARIDELJOU MJ. Genetic engineering of lignin biosynthesis pathway improved stem bending disorder in cut gerbera (Gerbera jamesonii) flowers. Sci Hort. 2019; 245: 274-279.

12. HANSEN HV. A story of the cultivated Gerbera. The New Plantsman 1999; 6: 85-95.

13. HATAMZADEH A, AKBARI R, SARIRI R, BAKHSHI D. Comparison of parameters affecting flower color in Gerbera hybrida: A phytochemical study on new varieties. J Agri Sci. 2012; 4(11): 186-194.

14. HOSSAIN S, JOLLY SN, PARVIN S, MEHRAJ H et al. Performance on growth and flowering of sixteen hybrid gerbera cultivars. Int J Bus Soc Sci Res. 2015; 3(2): 87-92.

15. JEEVAJOTHI L, BALAKRISHNAMOORTHY G, MURUGESAN R, RAJAMANI K et al. Performance of gerbera under different growing structures. South Indian Hortic. 2003; 51(1-6): 66-69.

16. KHAN P, MEHRAJ H, TAUFIQUE T, SHIAM IH et al. Chemical preservatives for increasing shelf life of gerbera. J Biosci Agric Res. 2015; 05(01): 30-36.

17. LI F, LI S, SHAN Q. The effect of temperature on plant growth in four Gerbera hybrida cultivars. HortScience. 2019; 54(7): 1164-1167.

18. LONGCHAR A, KEDITSU R. Flower yield and vase life of Gerbera in response to planting time and organic manures on Alfisol. Sci J Agri 2013; 2(3): 124-128.

19. MAHMOOD MA, AHMAD N, KHAN MS. Comparative evaluation of growth, yield and quality characteristics of various gerbera (Gerbera jamesonii L.) cultivars under protected condition. J Orn Plants. 2013; 3(4): 235-241.

20. MAROUSKY FJ. Vascular structure of the Gerbera scape. Acta Hort. 1986; 181: 399-406.

21. MEMAN MA, DABHI KM. Effect of different stalk lengths and certain chemical substances on vase life of gerbera (Gerbera jamesonii Hook.) cv. 'Savana Red'. J ApplHortic. 2006; 8(2): 147-150.

22. MENG X, XING T, WANG X. The role of light in the regulation of anthocyanin accumulation in Gerbera hybrida. Plant Growth Regul. 2004; 44: 243-250.

23. NAIR SA, SINGH V, SHARMA TVRS. Effect of chemical preservatives on enhancing vase-life of Gerbera flowers. J Trop Agric. 2003; 41: 56-58.

24. PATIL SR, KULKARNI BS. Performance of gerbera cultivars under naturally ventilated poly house. Acta Hortic. 2015; 1104: 63-66.

25. PERIK RRJ, RAZE D, HARKEMA H, ZHONG $\mathrm{Y}$ et al. Bending in cut Gerbera jamesonii flowers relates to adverse water relations and lack of stem sclerenchyma development, not to expansion of the stem central cavity or stem elongation. Postharvest Bio Techol. 2012; 74: 11-18.

26. PETTERSEN RI, GISLEROD HR. Effects of lighting period and temperature on growth, yield and keeping quality of Gerbera jamesonii Bolus. Europ J Hort Sci. 2003; 68: 32-37.

27. SARKAR I, GHIMIRAY TS. Performance of gerbera under protected condition in hilly region of West Bengal. J OrnaHortic. 2004; 7(3\&4): 230-234.

28. SHAMMY FH, SOLAIMAN AHM, DAS C, ISLAM MS et al. Growth and flowering characteristics of two potted gerbera (Gerbera jamesonii L.) varieties. J ExptBiosci. 2012; 3(1): 33 -36.

29. TOURJEE KR, HARDING J, BYRNE TG. Early development of gerbera as a floricultural crop. HortTechnology. 1994; 4(1): 34-40.

30. DE VISSER PHB, KÖRNER O, VAN NOORT FR, MARCELIS LFM. Parapluplan Gerbera. Deelproject 6: Voorspellen enSturen. Rapport GTB-1049. 2010. Wageningen-UR Glastuinbouw, Netherlands.

31. WERNETT HC, SHEEHAN TJ, WILFRET GJ, MAROUSKY FJ et al. Postharvest longevity of cutflower gerbera. I. Response to selection for vase life components. J Amer Soc Hort Sci. 1996; 121(2): 216-221.

32. ZAHARIA A, CANTOR M, BORSAI O, ERZSEBET B, JUCAN D. Correlation analysis of different morphological characters among cultivars and hybrids of Gladiolus hybridus Hort. Romanian Biotechnological Letters 2018; 23(4): 13723-13727. 